\title{
$\mathrm{NaOCI}$ 처리 농도 및 시간에 따른 희귀식물 자란(Bletilla striata Rchb.f.)의 종자 발아 및 환력 연구
}

정영호 · 김진기 · 이하얀 · 송세규· 배기화

\section{Vitality and germination of Bletilla striata Rchb.f. seed according to treatment time and concentration of $\mathrm{NaOCl}$}

\author{
Young Ho Jung $\cdot$ Jinki Kim $\cdot$ Hayan Lee $\cdot$ Se-kyu Song $\cdot$ Kee Hwa Bae
}

Received: 7 November 2019 / Revised: 21 January 2020 / Accepted: 27 February 2020

(c) Korean Society for Plant Biotechnology

\begin{abstract}
This study was conducted to examine the vitality of Bletilla striata Rchb.f. seed treated with different concentrations sodium hypochlorite $(\mathrm{NaOCl})$ for different lengths of time. This study also examined the effect of $\mathrm{NaOCl}$ treatment times and concentrations on swelling formation and seed germination of $B$. striata seed. The non-treated $B$. striata seed had the highest survival rate $(82.7 \%)$ Treatment with more than $1.5 \% \mathrm{NaOCl}$ negatively affected the seed survival rate, as compared to concentrations of less than $1 \%$. The swelling formation and seed germination percentages were highest ( $90.1 \%$ and $94.1 \%$, respectively) when seeds were treated with $0.5 \% \mathrm{NaOCl}$ for $20 \mathrm{~min}$. These results can be used as important basic data for the growth and restoration of $B$. striata and further suggest the possibility of individual restoration in habitats.
\end{abstract}

Keywords Rare plants, Orchidaceae, Seed viability, swelled embryo

Y. H. Jung · K. H. Bae $(\bowtie)$

국립백두대간수목원 야생식물종자연구실

(Wild Plant Seed Research Division, Baekdudaegan National Arboretum, Bonghwa 36209, Republic of Korea)

e-mail: khbae7724@kiam.or.kr

J. Kim - H. Lee

국립백두대간수목원 시드볼트운영센터

(Seed Vault Center, Baekdudaegan National Arboretum, Bongwha 36209, Republic of Korea)

S. Song

국립백두대간수목원 산림생물자원보전실

(Biological Resources Conservation Division, Baekdudaegan

National Arboretum, Bonghwa 36209, Republic of Korea)

\section{서 언}

난초과(Orchidaceae)는 단자엽식물(monocotyledonous plant) 중 가장 진화한 식물로 알려져 있다. 그리고 식물계에서 가 장 큰 과(Family) 중의 하나이며 전 세계적으로 약 796속 17,500 여 종이 분포한다(Cribb et al. 2003). 또한 꽃과 잎, 줄기 의 모양이 매우 다양하고 아름다워 원예용, 조경용 등으로 육종이 되고 있다.

이 중 자란속(Bletilla)은 전 세계적으로 5종이 있고, 한국, 중국, 일본, 대만, 베트남 등 아시아 지역에만 자생한다. 자란 (Bletilla striata Rchb.f.)의 국내 자생지는 전라남도 지역의 해 안가이고, 자생지 생육환경은 토질이 양호하고 지중습도가 높은 지역이다. 야생 자란의 크기는 $50 \mathrm{~cm}$ 이고, 6 월에 화경 이 나와 3 7개의 홍자색 꽃이 총상으로 달린다(Lee 1993). 자란은 잎의 앞면에도 기공이 있어 다른 난초과 식물에 비해 엽육이 얇으면서도 햇빛에 강해서 노지재배가 가능한 호광 성 식물이다(Paek and Jeon 1995). 또한 꽃이 아름답고 관상적 가치가 매우 높아 야생에서의 무분별한 채취로 인해 개체수 가 급격하게 감소하고 있다(Korea Forest Service 2009). 이러 한 이유로 산림청에서는 세계자연보전연맹(IUCN: International Union for Conservation of Nature)의 평가기준에 따라 희귀식 물 취약종(VU: Vulnerable)레벨로 지정하여 보호하고 있다 (Korea Forest Service 2009). 또한, 자생지 분포 연구를 통해 본 자란의 자생지는 급격히 감소되었으며 해안가를 따라 분포 하는 자생지가 인근의 개발사업으로 인해 훼손되어 생존의 위협을 받고 있다.(Yoo et al. 2000).

야생에서 난초과 식물의 종자번식은 난균근균(Orchid mycorrhizal fungi) 없이는 발아가 어렵다(Smith and Read 2008; Rasmussen 1995). 난초과 식물의 종자는 양분(전분립)을 저장하는 배유 
가 없기 때문에 종피가 외부요인으로 인해 헐거워지기 전에 는 수분침투가 어렵다(Bae et al. 2010). 특수한 발아 매커니즘 이 있는 난초과 식물은 국내에서 몇몇 연구자들에 의해 산림 청 희귀식물로 지정된 광릉요강꽃(Cypripedium japonicum Thunb.), 복주머니란(Cypripedium macranthum Sw.), 털복주머 니란(Cypripedium guttatum Sw.), 보춘화(Cymbidium goeringii Rchb.f.) 등의 기내발아연구가 수행되었다(Bae et al. 2009; Bae et al. 2010; Bae et al. 2011). 자란에 관한 연구로는 당과 첨 가물이 자란의 발아 및 생육에 미치는 연구(Cho and Ahn 2000), 자란의 생육조절에 관한 연구(Yoo et al. 2001), 제주 용 암해수를 이용한 자란의 기내배양 연구(Bae et al. 2012) 등 다 양한 방법의 기내배양 연구들이 수행된 바 있다.

한편 우리가 일반적으로 세탁표백, 살균에 사용하는 락스 의 주성분인 차아염소산나트륨(NaOCl: Sodium hypochloride) 은 조직배양 실험에서 실험재료의 무균도입 중 미생물 제거 에 이용된다. 난초과 식물의 종자는 물의 투과가 어려운 종피 로 구성되어 있어 $\mathrm{NaOCl}$ 을 처리하면 종피 탈각처리 효과로 인한 수분과 산소의 투과성을 높일 뿐 아니라 발아억제물질 의 산화와 제거의 역할을 하여 발아율을 촉진시킨다고 알려 져 있다(Nakamura 1985: Bae et al. 2010). 광릉요강꽃, 털복주 머니란, 복주머니란의 연구 결과에 따르면 이들 종의 기내 종 자 배양시 $\mathrm{NaOCl}$ 처리는 초기 배의 발달과 프로토콤으로 발 달을 촉진한다는 결과가 보고된 바 있다(Bae et al. 2009; Bae et al. 2010; Bae et al. 2011). 따라서 본 연구는 $\mathrm{NaOCl}$ 처리시간과 농도에 따라 종자활력을 조사하고 배비대율 및 발아율을 조 사하였다. 분석결과를 바탕으로 산림청 지정 희귀식물로 분 류되는 자란의 기내 최적발아조건을 확립하는데 목적이 있다.

\section{재료 및 방법}

식물재료 및 기내배양조건

본 연구에 사용된 자란(B. striata) 종자는 2019년 9월에 제주 도 서귀포시에서 꼬투리 상태로 종자를 채집하여 사용하였 다. 채집된 식물재료는 표면을 깨끗이 씻고 건조기를 이용 하여 물기를 제거한 다음 실리카겔이 포함된 종자 보관병에 담아 $4^{\circ} \mathrm{C}$ 단기저장고에서 1 개월간 저온처리를 하였다. 종자 발아는 온도 $24 \pm 1{ }^{\circ} \mathrm{C}$, 광주기는 12/12시간, 그리고 광도 46 $\mu \mathrm{mol} \mathrm{m} \mathrm{m}^{-2} \mathrm{~s}^{-1}$ 의 배양 챔버에서 실시하였다. 실험에 사용한 모 든 배지와 기구는 $121^{\circ} \mathrm{C}, 1.5$ 기압으로 20 분간 고온·고압 멸 균하여 페트리디쉬에 $30 \mathrm{~mL}$ 씩 배지를 분주하여 실험에 사 용하였다.

$\mathrm{NaOCl}$ 처리시간 및 농도에 따른 종자활력(TZ) 검증

$\mathrm{NaOCl}$ 처리 농도와 시간에 따라 자란의 종자활력을 검증하
기 위해 $1 \%$ triphenol tetrazolium chloride(TZ) 용액을 사용하 였다. 자란의 종자를 꼬투리에서 꺼내 시간별, 농도별로 $\mathrm{NaOCl}$ 을 처리한 후 멸균수로 3회 세척하여 TZ용액에 각각 500개 이상을 침지하여 $30^{\circ} \mathrm{C}$ 암조건에서 48 시간 반응하고 이후 증 류수로 5 회 세척하였다. 활력유무의 판정은 $\mathrm{TZ}$ 용액으로 자 란의 배가 붉게 염색되는 것을 활력이 있음으로 판정하고 염 색이 되지 않으면 비활력으로 판정하였다(van Waes and Deberg 1986). 또한 $\mathrm{NaOCl}$ 처리 농도, 시간에 따라 자란의 종자활력 을 확인하기 위해 세척 후 실체현미경을 이용하여 자란 종자 의 붉게 염색된 부위를 조사하였다.

\section{$\mathrm{NaOCl}$ 처리시간 및 농도에 따른 배비대와 종자발아}

$\mathrm{NaOCl}$ 의 처리시간과 농도가 자란의 종자발아에 미치는 영 향을 알아보기 위해 자란의 꼬투리를 $70 \%$ 에탄올에 1 회 30 초간 표면 살균한 후 멸균된 증류수로 3 회 수세하였다. 꼬투 리를 열 개하여 종자를 수확한 다음 $\mathrm{NaOCl}$ 처리시간 $(0,5,10$, 15 분 $)$ 과 농도 $(0,0.5,1,1.5,2 \%)$ 를 달리하여 처리하였다. $\mathrm{NaOCl}$ 이 처리된 종자는 멸균수로 5 회 수세하여 $\mathrm{NaOCl}$ 을 완 전히 제거한 후 배양하였다. 자란의 기내 종자발아를 위한 배지는 SGM(Seed Germination Medium, Sigma, USA) 배지를 사용하였다. 배비대율(embryo swelling)과 발아율 조사는 2일 간격으로 총 15 회 수행하였으며 4 주후에 결과를 분석하였다.

\section{통계분석}

모든 데이터는 means \pm standard deviation으로 표시하였다. 정 규성 검정 결과 정규분포를 띄지 않아 비모수 통계분석인 Mann-Whitney U test를 실시하였다. 통계적 유의성은 P < 0.05 로 설정하여 분석하였다.

\section{결과 및 고찰}

\section{$\mathrm{NaOCl}$ 처리에 따른 자란의 종자활력}

산림청 지정 희귀식물인 자란(B. striata)의 종자발아 중 최적 의 $\mathrm{NaOCl}$ 처리시간 $(5,10,15,20$ 분 $)$ 과 농도 $(0,0.5,1.0,1.5$, $2.0 \%$ )를 알아보기 위해 종자활력을 검증하였다. 그 결과, $\mathrm{NaOCl}$ 무처리구와 $0.5 \%, 1 \%$ 농도 처리구에서 붉은색의 염 색부위가 관찰되었다(Fig. 1A). 자란종자의 활력은 $\mathrm{NaOCl}$ 농 도에 따라 활력차이를 보였으며 비교적 높은 $\mathrm{NaOCl}$ 농도인 $1.5 \%$ 또는 $2 \%$ 로 처리하였을 때 $\mathrm{NaOCl}$ 처리 시간과 관계없 이 붉은색의 염색부위가 관찰 되지 않았다(Fig. 1B). 또한, $\mathrm{NaOCl}$ 을 $1 \%$ 처리 하였을 때의 종자활력은 $0.5 \%$ 처리하였을 때에 비해 급격히 낮아지는 결과를 보였다(Fig. 2). 이러한 결과 는 기존의 한라천마(Gastrodia verrucosa)와 애기천마 (Hetaeria 

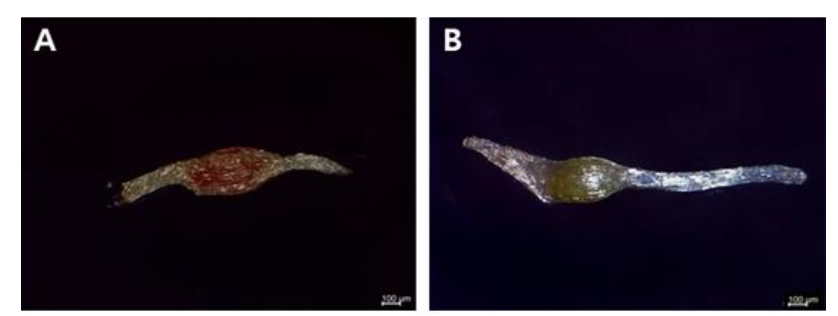

Fig. 1 Seed viability test of seed embryo of B. striata. A: treated with $0.5 \% \mathrm{NaOCl}$ for $5 \mathrm{~min}, \mathrm{~B}$ : treated with $1.5 \% \mathrm{NaOCl}$ for $5 \mathrm{~min}$

sikokiana)의 경우 비교적 높은 $\mathrm{NaOCl}$ 농도인 $2 \%$ 또는 $4 \%$ 에 15 분 이상 처리하면 종자생존이 급감한다는 연구 결과와 비 슷한 결과를 보였다(Bae et al. 2012). 하지만 본 연구 결과에 서 자란의 경우 $\mathrm{NaOCl}$ 을 $2 \%$ 처리하였을 경우 처리시간과 관계없이 낮은 종자활력을 보였는데(Fig. 2) 이는 한라천마 와 애기천마와는 다른 결과를 나타냈다. 이러한 결과로 볼 때 같은 $\mathrm{NaOCl}$ 농도라도 종 별로 종자활력에 미치는 영향이 다르며 자란 종자가 한라천마나 애기천마 종자보다 $\mathrm{NaOCl}$ 농도에 더 민감한 것으로 보인다. $\mathrm{NaOCl}$ 무처리구 자란종자 는 $80 \%$ 이상의 가장 높은 활력을 보였지만 배의 비대와 발아 는 $50 \%$ 로 조사되어 $0.5 \%$ 의 $\mathrm{NaOCl}$ 처리구보다 낮은 발아율 을 나타냈다(Table 1, Fig. 2).

\section{$\mathrm{NaOCl}$ 처리에 따른 배비대율 및 종자발아}

자란의 배비대율과 종자발아를 조사하기 위해 $\mathrm{NaOCl}$ 의 처

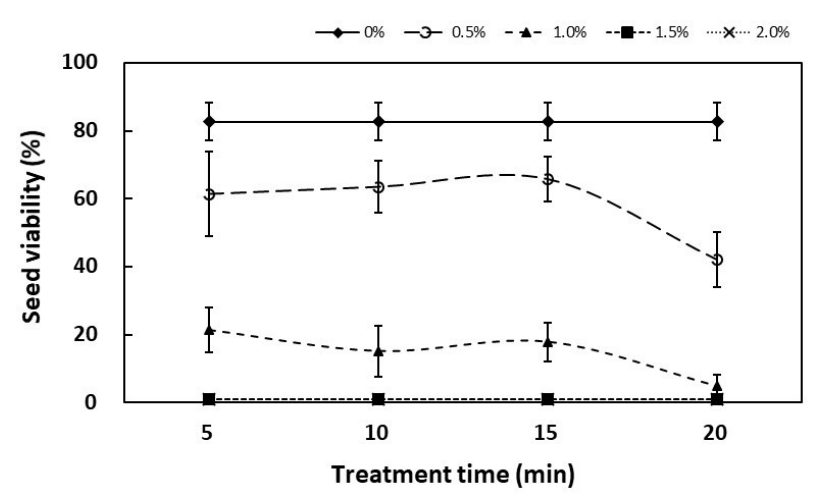

Fig. 2 Effects of treatment time and concentration of $\mathrm{NaOCl}$ on seed viability of $B$. striata

리시간과 농도를 달리하여 실험을 수행한 결과, $\mathrm{NaOCl}$ 처리 농도 $0.5 \%$, 처리시간 20 분을 처리할 때 배비대율과 발아율 이 각각 $90 \%$ 와 $94 \%$ 로 가장 높은 결과를 나타냈다(Table 1). 하지만 동일한 $\mathrm{NaOCl} 0.5 \%$ 처리농도에서 처리시간에 따른 배비대율과 발아율 간에 통계적으로 유의한 차이는 없었다 (Table 1). 한편, $\mathrm{NaOCl}$ 무처리구 보다 $\mathrm{NaOCl}$ 을 처리한 경우 배비대율과 발아율이 높게 나타난 결과는 $\mathrm{NaOCl}$ 처리를 통 해 털복주머니란, 애기천마와 한라천마의 기내 발아율을 증 가시킨 연구 결과와 일치한다(Bae et al. 2009; Bae et al. 2012). 자란의 배비대율은 $\mathrm{NaOCl} 0.5 \%$ 농도 처리구에서 평균 $83.8 \%$ 로 조사되었고 배비대율 뿐 만 아니라 발아율도 높여 준다는 결과를 나타냈다(Table 1, Fig. $3 \mathrm{~A}, \mathrm{~B})$. 하지만 $\mathrm{NaOCl}$ $1.5,2.0 \%$ 처리구는 배비대와 발아가 이루어지지 않았다

Table 1 Effects of treatment time and concentration of $\mathrm{NaOCl}$ on swelling formation and germination B. striata seed after 4 weeks of culture on SGM medium. Data are presented as mean $\pm \mathrm{SD}$. The '*' mark indicates significant differences between treatments as determined by swelling formation and seed germination $(\mathrm{p}<0.05)$

\begin{tabular}{cllc}
\hline $\begin{array}{c}\text { Treatment time of } \mathrm{NaOCl} \\
(\mathrm{min})\end{array}$ & $\begin{array}{c}\mathrm{NaOCl} \text { concentration } \\
(\%)\end{array}$ & $\begin{array}{c}\text { Swelling } \\
\text { formation (\%) }\end{array}$ & $\begin{array}{c}\text { Seed } \\
\text { germination (\%) }\end{array}$ \\
\hline 0 & 0 & $51.4 \pm 3.1$ & $58.9 \pm 3.4$ \\
\hline & 0.5 & $78.4 \pm 5.3$ & $87.2 \pm 4.7$ \\
5 & $1^{*}$ & $31.5 \pm 1.6$ & $40.9 \pm 2.4$ \\
& 1.5 & 0 & 0 \\
\hline 2 & 0 & 0 \\
\hline & 0.5 & $87.4 \pm 3.2$ & $91.7 \pm 2.1$ \\
10 & $1^{*}$ & $42.4 \pm 2.9$ & $48.9 \pm 2.3$ \\
& 1.5 & 0 & 0 \\
& 2 & 0 & 0 \\
\hline & 0.5 & $79.3 \pm 4.9$ & $85.5 \pm 3.5$ \\
& $1 *$ & $42.6 \pm 1.4$ & 0 \\
& 1.5 & 0 & 0 \\
\hline & 2 & 0 & $94.1 \pm 3.0$ \\
& 0.5 & $90.1 \pm 4.6$ & $49.6 \pm 2.5$ \\
& $1 *$ & $41.3 \pm 3.5$ & 0 \\
& 1.5 & 0 & 0 \\
\hline
\end{tabular}



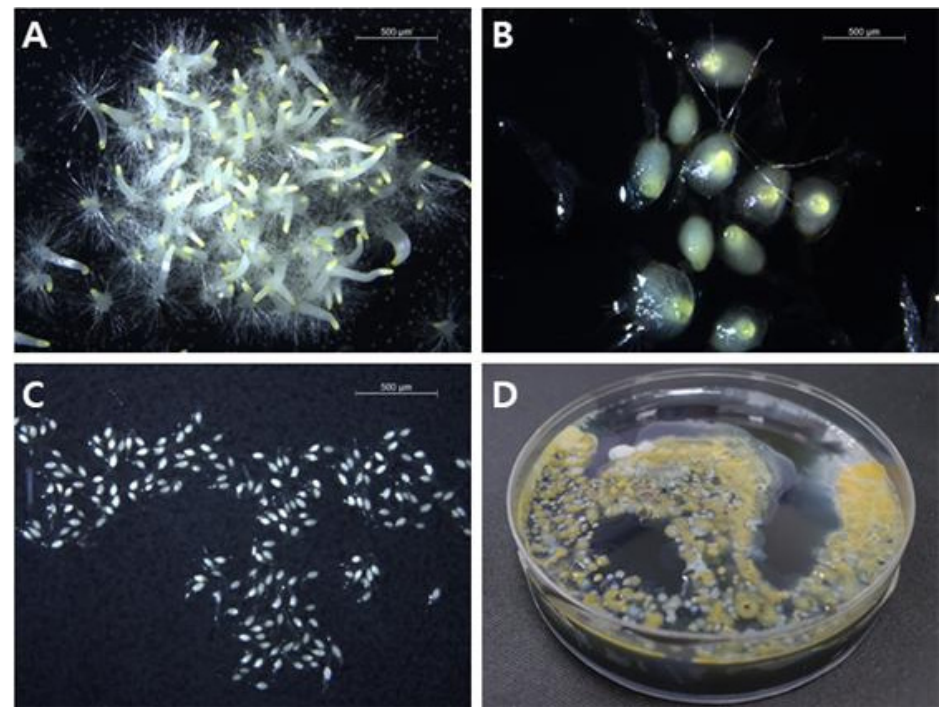

Fig. 3 Medium conditions according to treatment time and concentration of $\mathrm{NaOCl}$ from seed of $B$. striata 4 weeks after sowing. A: treated with $0.5 \% \mathrm{NaOCl}$ for 5 min (seed germination), B: treated with $1 \% \mathrm{NaOCl}$ for 5 min (swelling formation), C: treated with $1.5 \% \mathrm{NaOCl}$ for $5 \mathrm{~min}$ (non-germination), D: no treatment with $\mathrm{NaOCl}$ (medium contaminated by fungi and microorganisms)

(Table 1, Fig. 3C). 대조구로 사용한 $\mathrm{NaOCl}$ 무처리구는 배비 대율과 발아율이 각각 $51.4 \%$ 와 $58.9 \%$ 로 조사되었지만 곰팡 이와 미생물 오염이 $\mathrm{NaOCl}$ 처리구보다 2 배 이상 많았다(Fig. $3 \mathrm{D})$. 일반적으로 살균작용에 도움이 되는 $\mathrm{NaOCl}$ 의 특성상 $\mathrm{NaOCl}$ 을 처리하지 않은 배지가 $\mathrm{NaOCl}$ 을 처리한 배지보다 오염율이 높은 것으로 판단된다. 이러한 것으로 볼 때 종자 의 발아개시일이 다른 종자보다 오래 걸리는 난초과 식물 (Mathews and Rao 1980)의 발아 및 증식연구에서는 오염율을 낮추고, 발아율을 증가시키는 역할을 하는 $\mathrm{NaOCl}$ 을 종자에 직접 처리하는 것이 효과적일 것으로 판단된다.

$\mathrm{NaOCl} 0.5 \%$ 의 농도처리 중 처리시간은 배비대율과 발아 율 사이에 통계적으로 유의한 차이가 없었지만, $\mathrm{NaOCl} 1 \%$ 의 농도 처리 시에는 통계적으로 유의한 차이가 있었다 (Table 1). 이것으로 볼 때, $\mathrm{NaOCl}$ 농도를 $0.5 \%$ 처리하였을 때 는 배비대가 진행되면 대부분의 종자들이 발아까지 가능했 지만, 농도를 $1 \%$ 로 처리하였을 때는 배비대가 진행되어도 발아하지 못하는 종자가 생기는 것으로 보인다. 이러한 결 과는 $\mathrm{NaOCl}$ 의 종피 탈각처리 효과로 인해 종자의 종피가 탈 각된 후 $\mathrm{NaOCl}$ 이 배에 영향을 미친 결과로 해석된다.

따라서, 본 연구는 산림청 지정 희귀식물인 자란의 증 식과 야생에서의 개체복원을 위한 기내 종자활력과 발아 에 미치는 최적의 $\mathrm{NaOCl}$ 처리농도와 시간을 알아보고자 수행하였다. 이러한 연구결과는 향후 희귀 난초과식물의 개체증식과 복원에 중요한 기초자료로 활용될 것이다.

\section{사 사}

본 사업은 국립백두대간수목원 운영사업의 일환으로 수 행되었다.

\section{References}

Bae KH, Kwon HK, Choi YE (2009) In vitro germination and plantlet conversion from the culture of fully mature seeds of Cypripedium guttatum Swartz. Propagation of Ornamental Plant 9:160-165

Bae KH, Kim CH, Sun BY, Choi YE (2010) Structural changes of seed coats and stimulation of in vitro germination of fully mature seeds of Cypripedium macranthos Swartz by $\mathrm{NaOCl}$ pretreatment. Propagation of Ornamental Plant 10:107-113

Bae KH, Choi YE (2011) Factors affecting fruit baring in natural habitat and in vitro culture of zygotic embryos of Cypripedium japonicum. Propagation of Ornamental Plant 11:146-152

Bae KH, Kim KJ, Kim NY, Song JM (2012) In vitro culture of rare plant Bletilla striata using Jeju magma seawater. Journal of Plant Biotechnology 39(4):281-287

Cho KH, Ahn YH (2000) Effect of sucrose and supplementary substances on the germination ecology and the seedling growth of native Bletilla striata. Korea Journal Environment Ecology 14(3):205-211

Cribb PJ, Kell SP, Dixon KW, Barrett RL (2003) Orchid conservation: a global perspective. Orchid conservation p.124

Korea Forest Service (2009) Rare plants data book in Korea National Arboretum Pocheon p.296

Lee TB (1993) Illustrated flora of Korea. Hyangmunsa Seoul, Korea. p.246

Mathews VH, Rao PS (1980) In vitro multiplications of Vanda hybrids through tissue culture technique. Plant Sci. Let. 17:383-389

Nakamura JI (1985) The Elements of Seed Science. Yokendo, 66-82

Paek KY, Jeon ES (1995) Stomatal density, size and morphological characteristics in Orchids. Journal of Korean Society Horticultural Science 36(6):851-862 
Rasmussen HN (1995) Terrestrial orchids: from seed to mycotrophic plant. Cambridge University Press

Smith SE, Read DJ (2008) Mycorrhizal symbiosis. Academic Press, NY

van Waes JM, Debergh PC (1986) In vitro germination of some Western European orchids. Physiologia Plantarum. 67:253-261

Yoo YK, Kim HK, Choi KH (2001) Regulation of growth and flowering by low temperature treatment in Bletilla striata. Journal of Korean Society Horticultural Science 42(2): 227-232

Yoo YK, Oh CG, Park CH (2000) Geographical distribution and vegetation of Bletilla striata Habitats. Journal of Korean Society Horticultural Science 41(2):212-216 